Article

\title{
Antioxidant, Antimicrobial and Antiproliferative Activities of Five Lichen Species
}

\section{Tatjana Mitrović ${ }^{1, *}$, Slaviša Stamenković ${ }^{1}$, Vladimir Cvetković ${ }^{1}$, Svetlana Tošić ${ }^{1}$, Milan Stanković ${ }^{2}$, Ivana Radojević ${ }^{2}$, Olgica Stefanović ${ }^{2}$, Ljiljana Čomić ${ }^{2}$, Dragana Đačić ${ }^{2}$, Milena Ćurčić ${ }^{2}$ and Snežana Marković ${ }^{2}$}

1 Department of Biology and Ecology, Faculty of Science and Mathematics, University of Niš, 33, Višegradska, 18000 Niš, Serbia; E-Mails: sslavisa@pmf.ni.ac.rs (S.S.); biovlada@yahoo.com (V.C); tosicsvetlana59@yahoo.com (S.T.)

2 Department of Biology and Ecology, Faculty of Science, University of Kragujevac, 12, Radoja Domanovića, 34000 Kragujevac, Serbia; E-Mails: mstankovic@kg.ac.rs (M.S.); ivana@kg.ac.rs (I.R.); olgicas@gmail.com(O.S.); ljilja@kg.ac.rs (L.Č.); dragandjacic@kg.ac.rs (D.Đ.); milenagen@gmail.com (M.Ć.); smarkovic@kg.ac.rs (S.M.)

* Author to whom correspondence should be addressed; E-Mail: tatjanamitrovic@hotmail.com; Tel.: +381-18-533-015; Fax: +381-18-533-014.

Received: 23 June 2011; in revised form: 15 August 2011 / Accepted: 19 August 2011 / Published: 23 August 2011

\begin{abstract}
The antioxidative, antimicrobial and antiproliferative potentials of the methanol extracts of the lichen species Parmelia sulcata, Flavoparmelia caperata, Evernia prunastri, Hypogymnia physodes and Cladonia foliacea were evaluated. The total phenolic content of the tested extracts varied from 78.12 to $141.59 \mathrm{mg}$ of gallic acid equivalent (GA)/g of extract and the total flavonoid content from 20.14 to $44.43 \mathrm{mg}$ of rutin equivalent $(\mathrm{Ru}) / \mathrm{g}$ of extract. The antioxidant capacities of the lichen extracts were determined by 2,2-diphenyl-1-picrylhydrazyl (DPPH) radicals scavenging. Hypogymnia physodes with the highest phenolic content showed the strongest DPPH radical scavenging effect. Further, the antimicrobial potential of the lichen extracts was determined by a microdilution method on 29 microorganisms, including 15 strains of bacteria, 10 species of filamentous fungi and 4 yeast species. A high antimicrobial activity of all the tested extracts was observed with more potent inhibitory effects on the growth of Gram $(+)$ bacteria. The highest antimicrobial activity among lichens was demonstrated by Hypogymnia physodes and Cladonia foliacea. Finally, the antiproliferative activity of the
\end{abstract}


lichen extracts was explored on the colon cancer adenocarcinoma cell line HCT-116 by MTT (3-[4,5-dimethylthiazol-2-yl]-2,5-diphenyltetrazolium bromide) viability assay and acridine orange/ethidium bromide staining. The methanol extracts of Hypogymnia physodes and Cladonia foliacea showed a better cytotoxic activity than the other extracts. All lichen species showed the ability to induce apoptosis of HCT-116 cells.

Keywords: lichens extract; total phenolic content; antioxidant activity; antimicrobial activity; antiproliferative activity

\section{Introduction}

Lichens are a unique life form of symbiosis between fungi (mycobionts) and algae and/or cyanobacteria (photobionts). They are considered to be the earliest colonizers of terrestrial habitats on the earth [1]. Nowadays, 25,000 different species of lichens inhabit over $10 \%$ of the terrestrial surface from arctic to tropical regions and from the plains to the highest mountains [2]. The specific, even extreme, conditions of their existence, slow growth and long duration (maximum lifetime spans to several thousand years) are consistent with their abundance in protective metabolites against different physical and biological influences [3].

Generally, lichens metabolites can be divided into two groups: primary and secondary. Primary metabolites are proteins, lipids, carbohydrates and other organic compounds involved in lichen's metabolism and structure. Secondary metabolites, known as lichens substances, are mostly small, but complex molecules. Structures for more than 1050 different lichen substances have been reported to date [4]. They are produced by the fungus or the alga per se, while others are exclusively produced by synergistic action of both partners in lichens. Secondary metabolites are usually insoluble in water and can be extracted into organic solvents. Their amount ranges from 0.1 to $10 \%$ of the dry weight of tallus and sometimes reaches 30\% [2]. Secondary metabolites exert a remarkable variety of biological effects: antiviral, antibacterial, antifungal, antiprotozoal, antiherbivore, antimutagenic, antioxidant, antitumor, antiulcerogenic, antinociceptive, antipyretic and anti-inflammatory activities. These effects were exploited in traditional medicine for treatment of various conditions (external wounds, burns, gastritis, cold, asthma, tuberculosis, etc.) in humans and animals since Egyptian times.

Nowadays, the imbalance between intracellular antioxidants and intracellular reactive oxygen species (ROS) or the so-called state of oxidative stress is a known contributing factor to over a hundred diseases. Antioxidants prevent oxidative damage of biomolecules and cells and ROS-induced diseases by reacting with free radicals, scavenging free radicals and chelating free catalytic metals [5]. The prevention with synthetic antioxidants (butylated hydroxyanisole (BHA), butylated hydroxytoluene (BHT), tert-butylhydroquinone (TBHQ) and propyl gallate (PG)) exerts a toxic and carcinogenic effect [6]. A strong antioxidant power of some lichen species was demonstrated in several studies [7-14].

The growing population of drug-resistant microorganisms and the problem of treating the infections induced have motivated the search for alternative antimicrobial drugs in lichens. The antibacterial activity against Gram (+) and Gram (-) bacteria, as well as the antifungal activity is shown for many lichen species [2,15-21]. 
Furthermore, the antitumor potential of lichen flora is investigated. Perry et al. screened a collection of 69 lichen species for their antiproliferative activity [22]. A high proportion of the lichen extracts manifested a cytotoxic activity against BS-C-1 (African green monkey kidney) cells and/or P388 (murine leukemia) cells. Ten lichen substances were reported as cytotoxic [23]. The most famous among them are: usnic acid, protolichesterinic- and lobaric acids [24-26].

The aim of this study is the evaluation of the antioxidant, antimicrobial and antiproliferative capacities of the most abundant lichen species in the southeast of Serbia (Parmelia sulcata, Flavoparmelia caperata, Evernia prunastri, Hypogymnia physodes and Cladonia foliacea).

\section{Results and Discussion}

\subsection{Total Phenolic Content, Total Flavonoid Content and Antioxidant Activity}

The antioxidant potential of methanol extract of Parmelia sulcata, Flavoparmelia caperata, Evernia prunastri, Hypogymnia physodes and Cladonia foliacea was estimated by determining their total phenolic and flavonoid contents and their ability for free radical scavenging. The results are shown in Table 1.

Table 1. The comparison of the total phenolic content, the total flavonoid content and the antioxidant activity of the lichen extracts.

\begin{tabular}{|c|c|c|c|c|}
\hline Lichen species & $\begin{array}{c}\text { Total phenolic } \\
\text { content } 1, *\end{array}$ & $\begin{array}{c}\text { Total flavonoid } \\
\text { content }\end{array}$ & $\begin{array}{l}\text { Antioxidant } \\
\text { Activity }{ }^{3, *}\end{array}$ & Chemical composition \\
\hline $\begin{array}{l}\text { Parmelia } \\
\text { sulcata }\end{array}$ & $88.25 \pm 1.02$ & $44.43 \pm 1.22$ & $584.22 \pm 1.28$ & $\begin{array}{l}\text { Arabinitol, atraric acid, atranol, } \alpha \text {-tocopherol, } \\
\beta \text {-sitosterol, ergosterol, oleic acid, linolenic } \\
\text { acid, nonacosane, linoleic acid, palmitic acid, } \\
\text { methyl haematommate, olivetol, lichesterol, } \\
\text { stearic acid, salazinic acid, divaricatic acid } \\
{[27,28]}\end{array}$ \\
\hline $\begin{array}{l}\text { Flavoparmelia } \\
\text { caperata }\end{array}$ & $90.83 \pm 0.98$ & $33.55 \pm 0.93$ & $549.01 \pm 1.69$ & $\begin{array}{l}\text { Usnic acid, atraric acid, arabinitol, atranol, } \\
\text { orcinol, lichesterol, ergosterol, protocetraric } \\
\text { acid, caperatic acid [21,27,29] }\end{array}$ \\
\hline Evernia prunastri & $80.73 \pm 1.25$ & $27.46 \pm 0.78$ & $>1000.00$ & $\begin{array}{l}\text { Atraric acid, orcinol, usnic acid, methyl } \\
\text { orsellinate, orcinol monomethylether, methyl } \\
\text { haematommate, atranol, arabinitol, sparassol, } \\
\text { orsellinic acid, linoleic acid, oleic acid, } \\
\text { stearic acid, palmitic acid, lichesterol, } \\
\text { ergosterol, evernic acid }[28,30]\end{array}$ \\
\hline $\begin{array}{l}\text { Hypogymnia } \\
\text { physodes }\end{array}$ & $141.59 \pm 1.12$ & $20.14 \pm 0.81$ & $45.57 \pm 1.35$ & $\begin{array}{l}\text { Olivetol, atraric acid, olivetonide, olivetonic } \\
\text { acid, atranol, ergosterol, methyl } \\
\text { haematommate, lichesterol, oleic acid, stearic } \\
\text { acid, palmitic acid, linoleic acid, orcinol, } \\
\alpha \text {-tocopherol, hloroatranol, physodic acids, } \\
\text { physodalic acid, isophysodic acid, } \\
\text { 3-hydroxyphysodic acid, } \\
\text { 2'-O-methylphysodic acid [27,28,30,31] }\end{array}$ \\
\hline $\begin{array}{l}\text { Cladonia } \\
\text { foliacea }\end{array}$ & $78.12 \pm 1.31$ & $28.22 \pm 0.59$ & $>1000.00$ & $\begin{array}{l}\text { Usnic acid, atranorin, fumarprotocetraric acid } \\
\text { [32] }\end{array}$ \\
\hline
\end{tabular}


The total phenolic content of studied lichens extracts were determined by Folin-Ciocalteu method [33]. The amount of phenolic compounds varied from 78.12 to $141.59 \mathrm{mg} \mathrm{GA} / \mathrm{g}$ of extract. The highest phenolic content was found in Hypogymnia physodes and the lowest in Cladonia foliacea. The amount of phenolic compounds in Evernia prunastri was approximately the same as the amount in Cladonia foliacea. Parmelia sulcata and Flavoparmelia caperata showed close values of phenolic content.

The total flavonoid content was evaluated using aluminum chloride [34]. The amount of flavonoid compounds ranged from 20.14 to $44.43 \mathrm{mg} \mathrm{Ru} / \mathrm{g}$ of lichen extract. The highest flavonoid content was identified in Parmelia sulcata and the lowest in Hypogymnia physodes. Evernia prunastri and Cladonia foliacea had approximately the same values of the total flavonoid content.

DPPH radical scavenging capacities of lichen were measured by the modified method of Tekao et al. [35,36]. The observed values of $\mathrm{IC}_{50}$, i.e., the concentration of extract decreasing the initial DPPH concentration to $50 \%$, varied from 45.57 to $>1000.00 \mu \mathrm{g} / \mathrm{mL}$. The DPPH radical scavenging capacity of Hypogymnia physodes was significantly higher than the capacity of the other four samples $(45.57 \mu \mathrm{g} / \mathrm{mL})$. Evernia prunastri and Cladonia foliacea showed the lowest scavenging capacity. Parmelia sulcata and Flavoparmelia caperata showed a similar ability for scavenging DPPH radicals.

The antioxidant activity of lichen species Evernia prunastri and Cladonia foliacea has not been previously investigated. The comparison of the chemical content of the tested extracts and their free radical scavenging ability revealed a strong correlation which was in accordance with the previous results from Rankovic, Kosanic and colleagues [12,13]. An oposite finding of Odabasoglu et al. with methanol extracts of Lobaria pulmonaria and Usnea longissima, were explained by the participation of other, non-polar components, insoluble in methanol in this activity [37].

A list of compounds previously detected in methanol extracts of Parmelia sulcata, Flavoparmelia caperata, Evernia prunastri, Hypogymnia physodes and Cladonia foliacea is given in Table 1. Lichen phenolic substances-depsides, depsidones and dibenzofurans, are well known for their antioxidant activities [12,35,36]. Also, one should have in mind that the concentration of antioxidants fluctuates with environmental conditions. Extreme environmental conditions (high temperature, high light, desiccation, rehydratation, air pollution) reduce synthesis of antioxidants in lichens and therefore decrease its antioxidant activity [39-41].

\subsection{Antimicrobial Activity}

The results of in vitro testing of the antibacterial and antifungal activities of the methanol extracts of lichens Parmelia sulcata, Flavoparmelia caperata, Evernia prunastri, Hypogymnia physodes and Cladonia foliacea are shown in Tables 2-5.

The antimicrobial activity of lichen extracts was evaluated by microdilution method with resazurin [42]. The minimum inhibitory concentrations (MIC) and the minimum microbicidal concentrations (MMC) of extracts were determined on the collection of 29 microorganisms including 15 strains of bacteria, 10 species of filamentous fungi and 4 species of yeasts. MIC and MMC values ranged from $9.8 \times 10^{-3} \mathrm{mg} / \mathrm{mL}$ to $40.00 \mathrm{mg} / \mathrm{mL}$ (Tables $2-5$ ). The tested extracts showed different levels of antimicrobial activity depending on the group of microorganisms $(\operatorname{Gram}(+), \operatorname{Gram}(-)$, bacteria, filamentous fungi, yeasts) and the species of lichens. In general, lichen methanol extracts 
demonstrated a high antimicrobial activity. Their inhibitory effect was the most potent on Gram $(+)$ bacteria and the weakest on yeasts. Three lichen species Evernia prunastri, Hypogymnia physodes and Cladonia foliacea manifested the strongest antimicrobial activity $(\mathrm{p}<0.05)$.

Table 2. The antibacterial activity of the methanol extracts of lichens Parmelia sulcata, Flavoparmelia caperata and Evernia prunastri.

\begin{tabular}{|c|c|c|c|c|c|c|c|c|}
\hline \multirow[b]{2}{*}{ Species } & \multicolumn{2}{|c|}{ Parmelia sulcata } & \multicolumn{2}{|c|}{ Flavoparmelia caperata } & \multicolumn{2}{|c|}{ Evernia prunastri } & \multicolumn{2}{|c|}{ Doxycycline } \\
\hline & MIC * & MMC * & MIC * & MMC * & MIC * & MMC * & MIC * & MMC * \\
\hline Sarcina lutea & $3.13 \times 10^{-1}$ & $3.13 \times 10^{-1}$ & $7.81 \times 10^{-2}$ & $7.81 \times 10^{-2}$ & $7.81 \times 10^{-2}$ & $7.81 \times 10^{-2}$ & $<4.48 \times 10^{-4}$ & $3.75 \times 10^{-3}$ \\
\hline $\begin{array}{l}\text { Enterococcus } \\
\text { faecalis }\end{array}$ & 10.00 & 10.00 & 10.00 & 10.00 & 10.00 & 10.00 & $7.81 \times 10^{-3}$ & $6.25 \times 10^{-2}$ \\
\hline $\begin{array}{l}\text { Enterococcus } \\
\text { faecalis } \\
\text { ATCC } 29212\end{array}$ & 5.00 & 5.00 & $7.81 \times 10^{-2}$ & $1.56 \times 10^{-1}$ & $3.13 \times 10^{-1}$ & $3.13 \times 10^{-1}$ & $7.81 \times 10^{-3}$ & $6.25 \times 10^{-2}$ \\
\hline Bacillus subtilis & $1.56 \times 10^{-1}$ & $3.13 \times 10^{-1}$ & $1.95 \times 10^{-2}$ & $3.91 \times 10^{-2}$ & $3.91 \times 10^{-2}$ & $3.91 \times 10^{-2}$ & $1.12 \times 10^{-4}$ & $1.95 \times 10^{-3}$ \\
\hline $\begin{array}{l}\text { Bacillus subtilis } \\
\text { ATCC } 6633\end{array}$ & $7.81 \times 10^{-2}$ & $1.56 \times 10^{-1}$ & $1.95 \times 10^{-2}$ & $1.95 \times 10^{-2}$ & $3.91 \times 10^{-2}$ & $7.81 \times 10^{-2}$ & $1.95 \times 10^{-3}$ & $3.13 \times 10^{-2}$ \\
\hline Bacillus cereus & $3.13 \times 10^{-1}$ & $3.13 \times 10^{-1}$ & $3.91 \times 10^{-2}$ & $3.91 \times 10^{-2}$ & $7.81 \times 10^{-2}$ & $7.81 \times 10^{-2}$ & $9.77 \times 10^{-4}$ & $7.81 \times 10^{-3}$ \\
\hline $\begin{array}{l}\text { Staphylococcus } \\
\text { aureus }\end{array}$ & $3.13 \times 10^{-1}$ & 1.25 & $1.56 \times 10^{-1}$ & $1.56 \times 10^{-1}$ & $1.56 \times 10^{-1}$ & $3.13 \times 10^{-1}$ & $4.48 \times 10^{-4}$ & $7.81 \times 10^{-3}$ \\
\hline $\begin{array}{l}\text { Staphylococcus } \\
\text { aureus } \\
\text { ATCC } 25923\end{array}$ & 10.00 & 10.00 & $1.56 \times 10^{-1}$ & $3.13 \times 10^{-1}$ & $1.56 \times 10^{-1}$ & $6.25 \times 10^{-1}$ & $2.24 \times 10^{-4}$ & $3.75 \times 10^{-3}$ \\
\hline Escherichia coli & 5.00 & 5.00 & 10.00 & 10.00 & 10.00 & 10.00 & $7.81 \times 10^{-3}$ & $1.56 \times 10^{-2}$ \\
\hline $\begin{array}{l}\text { Escherichia coli } \\
\text { ATCC } 25922\end{array}$ & 5.00 & 5.00 & 10.00 & 10.00 & 10.00 & 10.00 & $1.56 \times 10^{-2}$ & $3.13 \times 10^{-2}$ \\
\hline $\begin{array}{l}\text { Pseudomonas } \\
\text { aeruginosa }\end{array}$ & 2.50 & 5.00 & 2.50 & 10.00 & 2.50 & 10.00 & $2.50 \times 10^{-1}$ & $2.50 \times 10^{-1}$ \\
\hline $\begin{array}{l}\text { Pseudomonas } \\
\text { aeruginosa } \\
\text { ATCC } 27853\end{array}$ & $6.25 \times 10^{-1}$ & 5.00 & $6.25 \times 10^{-1}$ & 10.00 & 2.50 & 20.00 & $6.25 \times 10^{-2}$ & $1.25 \times 10^{-1}$ \\
\hline Proteus mirabilis & 5.00 & 5.00 & 2.50 & 5.00 & 5.00 & 5.00 & 5.00 & $2.50 \times 10^{-1}$ \\
\hline Salmonella enterica & 5.00 & 5.00 & 10.00 & 20.00 & 10.00 & 20.00 & $1.56 \times 10^{-2}$ & $3.13 \times 10^{-2}$ \\
\hline $\begin{array}{l}\text { Salmonella } \\
\text { typhymirium }\end{array}$ & 5.00 & 5.00 & 10.00 & 10.00 & 10.00 & 20.00 & $1.56 \times 10^{-2}$ & $1.25 \times 10^{-1}$ \\
\hline
\end{tabular}

* Minimum inhibitory concentration (MIC) and minimum microbicidal concentration (MMC) values for lichen extracts and antibiotic are given as $\mathrm{mg} / \mathrm{mL}$. Antibiotic: Doxycycline.

The analysis of antibacterial activity indicated Hypogymnia physodes and Cladonia foliacea as the most potent extracts and Parmelia sulcata as the weakest one (Table 2 and Table 3). Hypogymnia physodes demonstrated the strongest activity on Gram $(+)$ bacteria Sarcina lutea (MIC and MMC values $<9.8 \times 10^{-3} \mathrm{mg} / \mathrm{mL}$ ) and Staphyloccocus aureus (MIC and MMC values $3.91 \times 10^{-2}$ and $\left.7.81 \times 10^{-2} \mathrm{mg} / \mathrm{mL}\right)($ Table 3$)$. Also, a high activity was shown on Gram (-) bacteria Pseudomonas aeruginosa, Pseudomonas aeruginosa ATCC 27853 and Proteus mirabilis with the same MIC values $\left(6.25 \times 10^{-1} \mathrm{mg} / \mathrm{mL}\right)$ and on Salmonella typhymirium with higher MIC value $(1.25 \mathrm{mg} / \mathrm{mL})$ (Table 3). 
The extract of Cladonia foliacea was the most effective against Gram (+) bacteria Bacillus subtilis, Bacillus subtilis ATCC 6633 and Bacillus cereus with the same MIC and MMC value $<9.8 \times 10^{-3} \mathrm{mg} / \mathrm{mL}$ (Table 3). The most resistant Gram (+) bacteria was Enterococcus faecalis and the most resistant Gram (-) bacteria was Escherichia coli.

Table 3. The antibacterial activity of the methanol extracts of lichens Hypogymnia physodes and Cladonia foliacea.

\begin{tabular}{|c|c|c|c|c|c|c|}
\hline \multirow[b]{2}{*}{ Species } & \multicolumn{2}{|c|}{ Hypogymnia physodes } & \multicolumn{2}{|c|}{ Cladonia foliacea } & \multicolumn{2}{|c|}{ Doxycycline } \\
\hline & MIC * & MMC * & MIC * & MMC * & MIC * & MMC * \\
\hline Sarcina lutea & $<9.80 \times 10^{-3}$ & $<9.80 \times 10^{-3}$ & $1.95 \times 10^{-2}$ & $3.91 \times 10^{-2}$ & $<4.48 \times 10^{-4}$ & $3.75 \times 10^{-3}$ \\
\hline Enterococcus faecalis & 5.00 & 10.00 & 20.00 & 20.00 & $7.81 \times 10^{-3}$ & $6.25 \times 10^{-2}$ \\
\hline $\begin{array}{l}\text { Enterococcus faecalis } \\
\text { ATCC } 29212\end{array}$ & $7.81 \times 10^{-2}$ & $7.81 \times 10^{-2}$ & $3.91 \times 10^{-2}$ & $3.91 \times 10^{-2}$ & $7.81 \times 10^{-3}$ & $6.25 \times 10^{-2}$ \\
\hline Bacillus subtilis & $7.81 \times 10^{-2}$ & $7.81 \times 10^{-2}$ & $<9.80 \times 10^{-3}$ & $<9.80 \times 10^{-3}$ & $1.12 \times 10^{-4}$ & $1.95 \times 10^{-3}$ \\
\hline $\begin{array}{l}\text { Bacillus subtilis } \\
\text { ATCC } 6633\end{array}$ & $3.91 \times 10^{-2}$ & $3.91 \times 10^{-2}$ & $<9.80 \times 10^{-3}$ & $<9.80 \times 10^{-3}$ & $1.95 \times 10^{-3}$ & $3.13 \times 10^{-2}$ \\
\hline Bacillus cereus & $7.81 \times 10^{-2}$ & $7.81 \times 10^{-2}$ & $<9.8 \times 10^{-3}$ & $<9.80 \times 10^{-3}$ & $9.77 \times 10^{-4}$ & $7.81 \times 10^{-3}$ \\
\hline $\begin{array}{l}\text { Staphylococcus } \\
\text { aureus }\end{array}$ & $3.91 \times 10^{-2}$ & $7.81 \times 10^{-2}$ & $3.91 \times 10^{-2}$ & $7.81 \times 10^{-2}$ & $4.48 \times 10^{-4}$ & $7.81 \times 10^{-3}$ \\
\hline $\begin{array}{l}\text { Staphylococcus } \\
\text { aureus } \\
\text { ATCC } 25923\end{array}$ & $3.13 \times 10^{-1}$ & $6.25 \times 10^{-1}$ & $7.81 \times 10^{-2}$ & $7.81 \times 10^{-2}$ & $2.24 \times 10^{-4}$ & $3.75 \times 10^{-3}$ \\
\hline Escherichia coli & 2.50 & 2.50 & 10.00 & 20.00 & $7.81 \times 10^{-3}$ & $1.56 \times 10^{-2}$ \\
\hline $\begin{array}{l}\text { Escherichia coli } \\
\text { ATCC } 25922\end{array}$ & 5.00 & 5.00 & 10.00 & 20.00 & $1.56 \times 10^{-2}$ & $3.13 \times 10^{-2}$ \\
\hline $\begin{array}{l}\text { Pseudomonas } \\
\text { aeruginosa }\end{array}$ & $6.25 \times 10^{-1}$ & 1.25 & 5.00 & 20.00 & $2.50 \times 10^{-1}$ & $>2.50 \times 10^{-1}$ \\
\hline $\begin{array}{l}\text { Pseudomonas } \\
\text { aeruginosa } \\
\text { ATCC } 27853\end{array}$ & $6.25 \times 10^{-1}$ & 2.50 & 1.25 & 2.50 & $6.25 \times 10^{-2}$ & $1.25 \times 10^{-1}$ \\
\hline Proteus mirabilis & $6.25 \times 10^{-1}$ & $6.25 \times 10^{-1}$ & 5.00 & 10.00 & $2.50 \times 10^{-1}$ & $>2.50 \times 10^{-1}$ \\
\hline Salmonella enterica & 1.25 & 10.00 & 10.00 & 20.00 & $1.56 \times 10^{-2}$ & $3.13 \times 10^{-2}$ \\
\hline $\begin{array}{l}\text { Salmonella } \\
\text { typhymirium }\end{array}$ & 1.25 & 2.50 & 10.00 & 20.00 & $1.56 \times 10^{-2}$ & $1.25 \times 10^{-1}$ \\
\hline
\end{tabular}

* Minimum inhibitory concentration (MIC) and minimum microbicidal concentration (MMC) values for lichen extracts and antibiotic are given as $\mathrm{mg} / \mathrm{mL}$. Antibiotic: Doxycycline.

In general, the antifungal activity of the tested lichen extracts was less prominent. The best results were obtained with Evernia prunastri and Hypogymnia physodes extracts. Evernia prunastri showed the best effect on yeasts (Table 4). Both, Evernia prunastri and Hypogymnia physodes, were active against Rhodotorula sp. with the same MIC and MMC values (1.25 and $2.5 \mathrm{mg} / \mathrm{mL}$, respectively) (Table 4 and Table 5). Aditionally, Evernia prunastri showed good results with filamentous fungi, especially Aspergillus niger ATCC 16404 with both MIC and MMC values of $1.56 \times 10^{-1} \mathrm{mg} / \mathrm{mL}$ (Table 4). Concerning Hypogymnia physodes, it demonstrated the highest activity on filamentous fungi. The best effect was observed on Aspergillus niger ATCC 16404 (MIC and MMC values 
$<9.8 \times 10^{-3} \mathrm{mg} / \mathrm{mL}$ ) (Table 5). Also, Hypogymnia physodes was the most potent against all representatives of Penicillium species (Table 5).

Table 4. The antifungal activity of the methanol extracts of lichens Parmelia sulcata, Flavoparmelia caperata, and Evernia prunastri.

\begin{tabular}{|c|c|c|c|c|c|c|c|c|}
\hline \multirow[b]{2}{*}{ Species } & \multicolumn{2}{|c|}{ Parmelia sulcata } & \multicolumn{2}{|c|}{ Flavoparmelia caperata } & \multicolumn{2}{|c|}{ Evernia prunastri } & \multicolumn{2}{|c|}{ Fluconazol } \\
\hline & MIC * & МMC * & MIC * & МMC * & MIC * & MMC * & MIC * & МMC * \\
\hline Candida albicans & 2.50 & 20.00 & 2.50 & 10.00 & 2.50 & 10.00 & $6.25 \times 10^{-2}$ & 1.00 \\
\hline $\begin{array}{l}\text { Candida albicans } \\
\text { ATCC } 10231\end{array}$ & 5.00 & 20.00 & 10.00 & 20.00 & 2.50 & 10.00 & $3.13 \times 10^{-2}$ & 1.00 \\
\hline Rhodotorula sp. & 2.50 & 2.50 & 2.50 & 5.00 & 1.25 & 2.50 & $6.25 \times 10^{-2}$ & 1.00 \\
\hline $\begin{array}{l}\text { Saccharomyces } \\
\text { boulardii }\end{array}$ & 10.00 & 20.00 & 10.00 & 40.00 & 5.00 & 10.00 & $3.13 \times 10^{-2}$ & 1.00 \\
\hline $\begin{array}{l}\text { Penicillium } \\
\text { italicum }\end{array}$ & 2.50 & 5.00 & 2.50 & 5.00 & 1.25 & 5.00 & 1.00 & 1.00 \\
\hline $\begin{array}{l}\text { Penicillium } \\
\text { chrysogenum }\end{array}$ & 2.50 & 2.50 & $6.25 \times 10^{-1}$ & 2.50 & 1.25 & 1.25 & $6.25 \times 10^{-2}$ & $5.00 \times 10^{-1}$ \\
\hline $\begin{array}{l}\text { Penicillium } \\
\text { digitatum }\end{array}$ & 1.25 & 1.25 & 5.00 & 10.00 & 1.25 & 1.25 & $3.13 \times 10^{-2}$ & $3.13 \times 10^{-2}$ \\
\hline Botrytis cinerea & 10.00 & 20.00 & 40.00 & 40.00 & 1.25 & 5.00 & $3.13 \times 10^{-2}$ & $5.00 \times 10^{-1}$ \\
\hline $\begin{array}{l}\text { Trichothecium } \\
\text { roseum }\end{array}$ & $6.25 \times 10^{-1}$ & $6.25 \times 10^{-1}$ & 2.50 & 5.00 & 1.25 & 5.00 & $5.00 \times 10^{-1}$ & $5.00 \times 10^{-1}$ \\
\hline Aspergillus niger & 10.00 & 20.00 & 2.50 & 20.00 & 1.25 & 5.00 & $5.00 \times 10^{-1}$ & 1.00 \\
\hline $\begin{array}{l}\text { Aspergillus niger } \\
\text { ATCC } 16404\end{array}$ & 2.50 & 2.50 & 10.00 & 40.00 & $1.56 \times 10^{-1}$ & $1.56 \times 10^{-1}$ & $6.25 \times 10^{-2}$ & $6.25 \times 10^{-2}$ \\
\hline $\begin{array}{l}\text { Aspergillus } \\
\text { restrictus }\end{array}$ & $6.25 \times 10^{-1}$ & $6.25 \times 10^{-1}$ & 5.00 & 5.00 & 1.25 & 1.25 & $5.00 \times 10^{-1}$ & 2.00 \\
\hline $\begin{array}{l}\text { Aspergillus } \\
\text { fumigatus }\end{array}$ & $<9.80 \times 10^{-3}$ & $<9.80 \times 10^{-3}$ & 1.25 & 1.25 & 1.25 & 1.25 & $5.00 \times 10^{-1}$ & 1.00 \\
\hline $\begin{array}{l}\text { Aspergillus } \\
\text { flavus }\end{array}$ & 1.25 & 2.50 & 2.50 & 5.00 & 1.25 & 5.00 & 1.00 & 1.00 \\
\hline
\end{tabular}

* Minimum inhibitory concentration (MIC) and minimum microbicidal concentration (MMC) values for lichen extracts and antimycotic are given as $\mathrm{mg} / \mathrm{mL}$. Antimycotic: Fluconazole.

Mostly, lichen extracts demonstrated a similar activity against standard and clinical strains of the same microorganism. Few exceptions were registered. Four out of five lichen species tested (Flavoparmelia caperata, Evernia prunastri, Hypogymnia physodes and Cladonia foliacea) acted differently on the standard and clinical bacterial strain of Enterococcus faecalis (Table 2 and Table 3). The extract of Parmelia sulcata showed a different effect on the standard and clinical bacterial strain of Staphylococcus aureus (Table 2). The extract of Hypogymnia physodes demonstrated a variability in affecting the standard and clinical strain of filamentous fungi Aspergillus niger (Table 5). 
Table 5. The antifungal activity of the methanol extracts of lichens Hypogymnia physodes and Cladonia foliacea.

\begin{tabular}{|l|c|c|c|c|c|c|}
\hline \multirow{2}{*}{ Species } & \multicolumn{2}{|c|}{ Hypogymnia physodes } & \multicolumn{2}{c|}{ Cladonia foliacea } & \multicolumn{2}{c|}{ Fluconazol } \\
\cline { 2 - 7 } & MIC * & MMC * & MIC * & MMC * & MIC * & MMC * \\
\hline Candida albicans & 5.00 & 20.00 & 5.00 & 20.00 & $6.25 \times 10^{-2}$ & 1.00 \\
\hline $\begin{array}{l}\text { Candida albicans } \\
\text { ATCC 10231 }\end{array}$ & 5.00 & 10.00 & 5.00 & 20.00 & $3.13 \times 10^{-2}$ & 1.00 \\
\hline Rhodotorula sp. & 1.25 & 2.50 & 1.25 & 5.00 & $6.25 \times 10^{-2}$ & 1.00 \\
\hline Saccharomyces boulardii & 10.00 & 20.00 & 5.00 & 40.00 & $3.13 \times 10^{-2}$ & 1.00 \\
\hline Penicillium italicum & 1.25 & 2.50 & 2.50 & 10.00 & 1.00 & 1.00 \\
\hline Penicillium chrysogenum & $6.25 \times 10^{-1}$ & 2.50 & 1.25 & 5.00 & $6.25 \times 10^{-2}$ & $5.00 \times 10^{-1}$ \\
\hline Penicillium digitatum & 1.25 & 1.25 & 5.00 & 5.00 & $3.13 \times 10^{-2}$ & $3.13 \times 10^{-2}$ \\
\hline Botrytis cinerea & 10.00 & 10.00 & 5.00 & 20.00 & $3.13 \times 10^{-2}$ & $5.00 \times 10^{-1}$ \\
\hline Trichothecium roseum & 1.25 & 2.50 & 10.00 & 20.00 & $5.00 \times 10^{-1}$ & $5.00 \times 10^{-1}$ \\
\hline Aspergillus niger & 5.00 & 10.00 & 20.00 & 20.00 & $5.00 \times 10^{-1}$ & 1.00 \\
\hline Aspergillus niger & & & & & & $6.25 \times 10^{-2}$ \\
ATCC 16404 & $<9.80 \times 10^{-3}$ & $<9.80 \times 10^{-3}$ & 10.00 & 10.00 & $6.25 \times 10^{-2}$ \\
\hline Aspergillus restrictus & 1.25 & 1.25 & 2.50 & 10.00 & $5.00 \times 10^{-1}$ & 2.00 \\
\hline Aspergillus fumigatus & 1.25 & 1.25 & $3.13 \times 10^{-1}$ & 2.50 & $5.00 \times 10^{-1}$ & 1.00 \\
\hline Aspergillus flavus & 1.25 & 1.25 & 2.50 & 10.00 & 1.00 & 1.00 \\
\hline
\end{tabular}

* Minimum inhibitory concentration (MIC) and minimum microbicidal concentration (MMC) values for lichen extracts and antimycotic are given as $\mathrm{mg} / \mathrm{mL}$. Antimycotic: Fluconazole.

The antimicrobial activity of the tested lichen species was examined in several studies in various ways and with different results. Ranković and colleagues observed the dependence of the level of the antimicrobial activity of the same lichen species on the solvent used in extraction [17]. They emphasized the strongest antimicrobial activity of the methanol extracts compared to the extracts in other solvents. This is consistent with the observation of Bezivin et al. that polar lichen compounds were mostly found in the methanol extract [23]. Besides this, the differences in previous studies could reflect: different quantity of the same active component in lichen extracts, different components involved in antimicrobial actions, different locations of lichen sampling, and different sensitivity of tested microorganisms or different methods of testing. Cansaran-Duman et al. underlined the dependence between a quantity of usnic acid possessed and the antimicrobial effect exhibited by various Hypogymnia species [43]. The higher the content of usnic acid in the species tested, the stronger the antimicrobial activity observed. Candan et al. connected the antimicrobial activities of Parmelia sulcata with salazinic acid constituents [44].

Our study of the antimicrobial properties of the methanol extracts of lichens Parmelia sulcata, Flavoparmelia caperata, Evernia prunastri, Hypogymnia physodes and Cladonia foliacea, showed a

different degree of antimicrobial activity depending on the tested group of microorganisms and the tested species. This is the first study of the antimicrobial activity of Evernia prunastri and Cladonia foliacea originating from our territory. Generally, the tested extracts demonstrated a good antimicrobial activity. Our study confirmed the highest antimicrobial activity of Hypogymnia physodes earlier noticed by Ranković and colleagues [17-21]. Also, the tested extracts showed more potent 
inhibitory effects on Gram $(+)$ bacteria than on other microorganisms, due to their specificity of the cell wall structure.

\subsection{Antiproliferative Activity}

The antiproliferative activity of methanol extracts of Parmelia sulcata, Flavoparmelia caperata, Evernia prunastri, Hypogymnia physodes and Cladonia foliacea was evaluated by the MTT viability assay and the acridine orange/ethidium bromide (AO/EB) double staining [45,46]. The colon cancer adenocarcinoma cell line HCT-116 was exposed to the various concentration of extract $(50-1000 \mu \mathrm{g} / \mathrm{mL})$ for a period of $24 \mathrm{~h}$ and $72 \mathrm{~h}$. After the treatment cell viability was measured by the MTT reduction assay. The results of the assay are represented in Figure 1.

Figure 1. The dose-response effect of lichen extracts on HCT-116 cells growth. The cells were treated with methanol extract in concentration range from $50-1000 \mu \mathrm{g} / \mathrm{mL}$. The antiproliferative effects were measured by MTT assay after 24 and $72 \mathrm{~h}$ exposure. Results were expressed as the means $\pm \mathrm{SE}$ from three independent experiments.

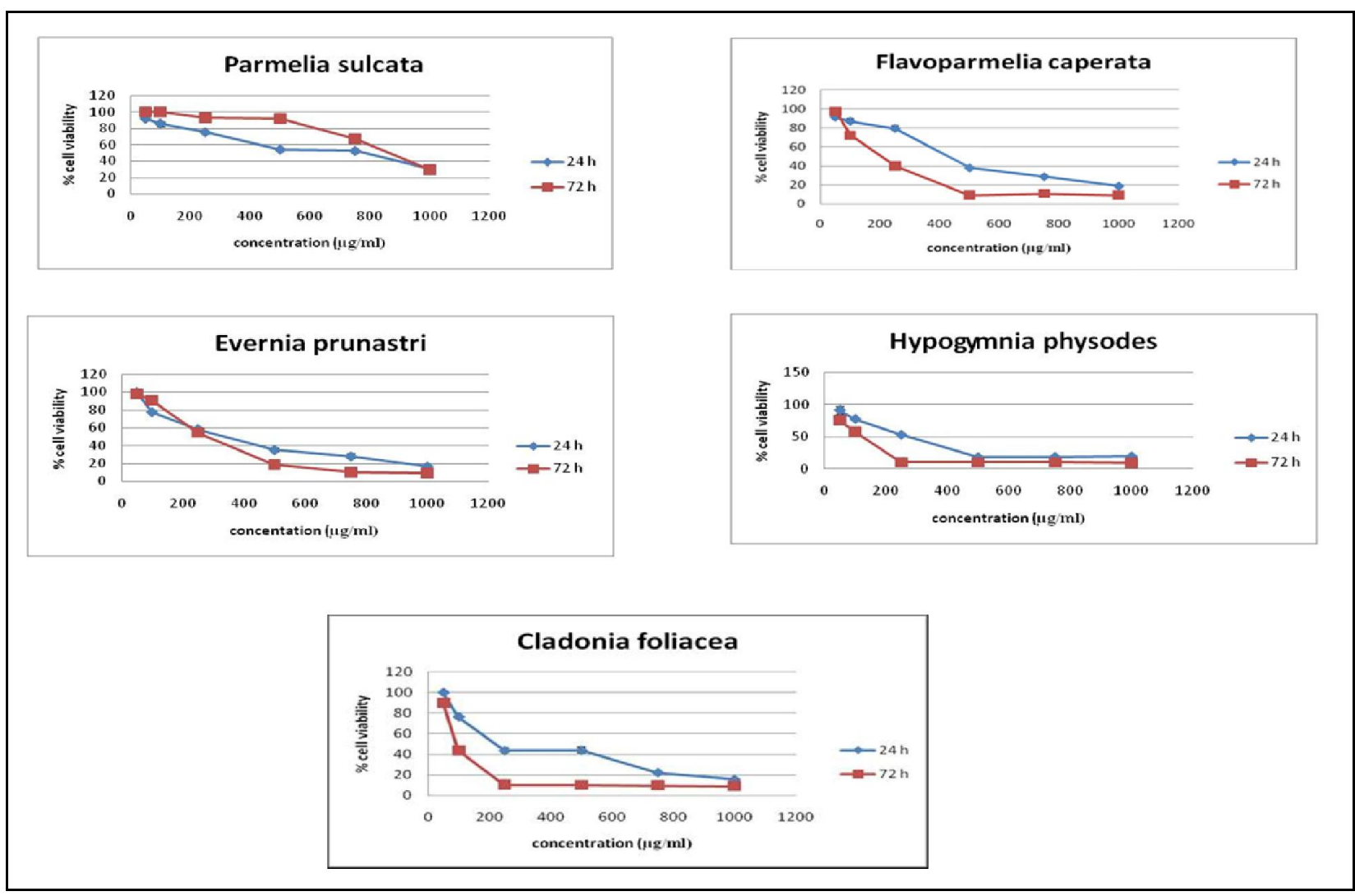

The extract of Parmelia sulcata did not induce a significant inhibition of cell growth in a dose- and time-dependent manner (Figure 1). The maximal inhibition was observed for the concentration of $1000 \mu \mathrm{g} / \mathrm{mL}$ after 24 and $72 \mathrm{~h}$ exposure. Extracts of Flavoparmelia caperata, Hypogymnia physodes and Cladonia foliacea demonstrated a significant inhibition of cell growth in a dose- and time-dependent manner (Figure 1). Hence, the higher the concentration of the extract applied, the higher cell sensitivity observed. The longer the time of the exposure, the higher cell sensitivity induced. Finally, extracts of Evernia prunastri manifested cell viability reduction in a dose-dependent 
manner. For a longer time of treatment $(72 \mathrm{~h}$ ), a higher cell sensitivity is observed, except with lower concentrations of extract (Figure 1). The comparison of the percentage of viable cells after 24 and after $72 \mathrm{~h}$, revealed a time-dependent reduction of cell viability for higher concentrations.

The antiproliferative effect of each extract was expressed by $\mathrm{IC}_{50}$ (inhibitory dose which inhibits $50 \%$ of cell growth) (Table 6). According to the American National Cancer Institute (NCI), a crude extract may be considered as active for an $\mathrm{IC}_{50}<30 \mu \mathrm{g} / \mathrm{mL}$ [47]. Based on this criterion, active substances in methanol extracts from Parmelia sulcata, Flavoparmelia caperata, Evernia prunastri, Hypogymnia physodes and Cladonia foliacea could not be described as cytotoxic.

Table 6. The growth inhibitory effects of the methanol extracts on HCT-116 cells expressed as $\mathrm{IC}_{50}$ values $(\mu \mathrm{g} / \mathrm{mL})$.

\begin{tabular}{|l|c|c|}
\hline \multirow{2}{*}{\multicolumn{1}{|c|}{ Lichen extract }} & \multicolumn{2}{|c|}{$\mathbf{I C}_{\mathbf{5 0}}(\boldsymbol{\mu} \mathbf{g} / \mathbf{m L})$} \\
\cline { 2 - 3 } & $\mathbf{2 4} \mathbf{~ h}$ & $\mathbf{7 2} \mathbf{~ h}$ \\
\hline Parmelia sulcata & $608.83 \pm 36.52$ & $913.03 \pm 63.91$ \\
\hline Flavoparmelia caperata & $397.64 \pm 19.88$ & $229.55 \pm 13.77$ \\
\hline Evernia prunastri & $303.47 \pm 15.25$ & $295.64 \pm 23.65$ \\
\hline Hypogymnia physodes & $253.72 \pm 17.76$ & $102.40 \pm 7.16$ \\
\hline Cladonia foliacea & $265.55 \pm 13.27$ & $122.47 \pm 9.79$ \\
\hline
\end{tabular}

The ability of the lichen extracts to induce apoptosis was screened by the acridine orange/ethidium bromide staining. According to the fluorescence emission and the morphological aspect of chromatin condensation in stained nuclei, four types of cells could be distinguished [46]. Viable cells (VC) possessed uniform bright green nuclei with organized structure and orange cytoplasm. Early apoptotic cells (EA), with intact membranes and initial DNA cleavage, were characterized by green nuclei with perinuclear chromatin condensation visible as bright green patches or fragments. Late apoptotic cells (LA) were recognized by orange to red nuclei with condensed or fragmented chromatin. Necrotic cells (N) exhibited uniformly orange to red nuclei with organized structure.

The results obtained with the acridine orange/ethidium bromide (AO/EB) staining of HCT-116 cells exposed $24 \mathrm{~h}$ to $250 \mu \mathrm{g} / \mathrm{mL}$ of various lichen extracts are shown in Figure 2 and Table 7 while the results for $72 \mathrm{~h}$ treatment are shown in Figure 3 and Table 8. The untreated, control HCT-116 cells were characterized by bright green nucleus with uniform intensity and the absence of ethidium bromide uptake, while apoptotic cells appeared orange (Figure 2a). HCT-116 cells treated with lichen extracts from all five species showed obvious nuclear condensation after $24 \mathrm{~h}$ of treatment (Figure $2 \mathrm{~b}-\mathrm{f}$ ). Fluorescence microscopic images clearly revealed nuclear disintegration of the treated cells compared to the untreated control cells. Compared with the spontaneus apoptosis observed in the control cells (early apoptotic $3.20 \%, 0 \%$ late apoptotic and $0 \%$ necrotic cells), HCT-116 cells treated with extracts of all lichen species showed increased percentages of early apoptotic cells for $24 \mathrm{~h}$ treatment. The extract of Hypogymnia physodes with the highest antiproliferative potential and $\mathrm{IC}_{50}$ of $253.72 \mu \mathrm{g} / \mathrm{mL}$ (Table 7$)$ showed increased percentages of early apoptotic $(42.22 \%)$, late apoptotic $(11.11 \%)$ and necrotic cells (17.78\%) after $24 \mathrm{~h}$ (Figure 2e). The extract of Cladonia foliacea showed maximal induction of early apoptotic phase (49.66\%) (Figure $2 \mathrm{f})$. 
Figure 2. The effect of the lichen extracts on the apoptosis of HCT-116 cells after $24 \mathrm{~h}$ exposure monitored by the acridine orange/ethidium bromide staining: (a) Untreated, control cells; (b) Cells treated with Parmelia sulcata extract; (c) Cells treated with Flavoparmelia caperata extract; (d) Cells treated with Evernia prunastri extract; (e) Cells treated with Hypogymnia physodes extract; (f) Cells treated with Cladonia foliacea extract. Magnification on fluorescent microscope was 400×; (g) Grafic representation of obtained data. VC - viable cell, EA - early apoptotic cell, LA - late apoptotic cell.

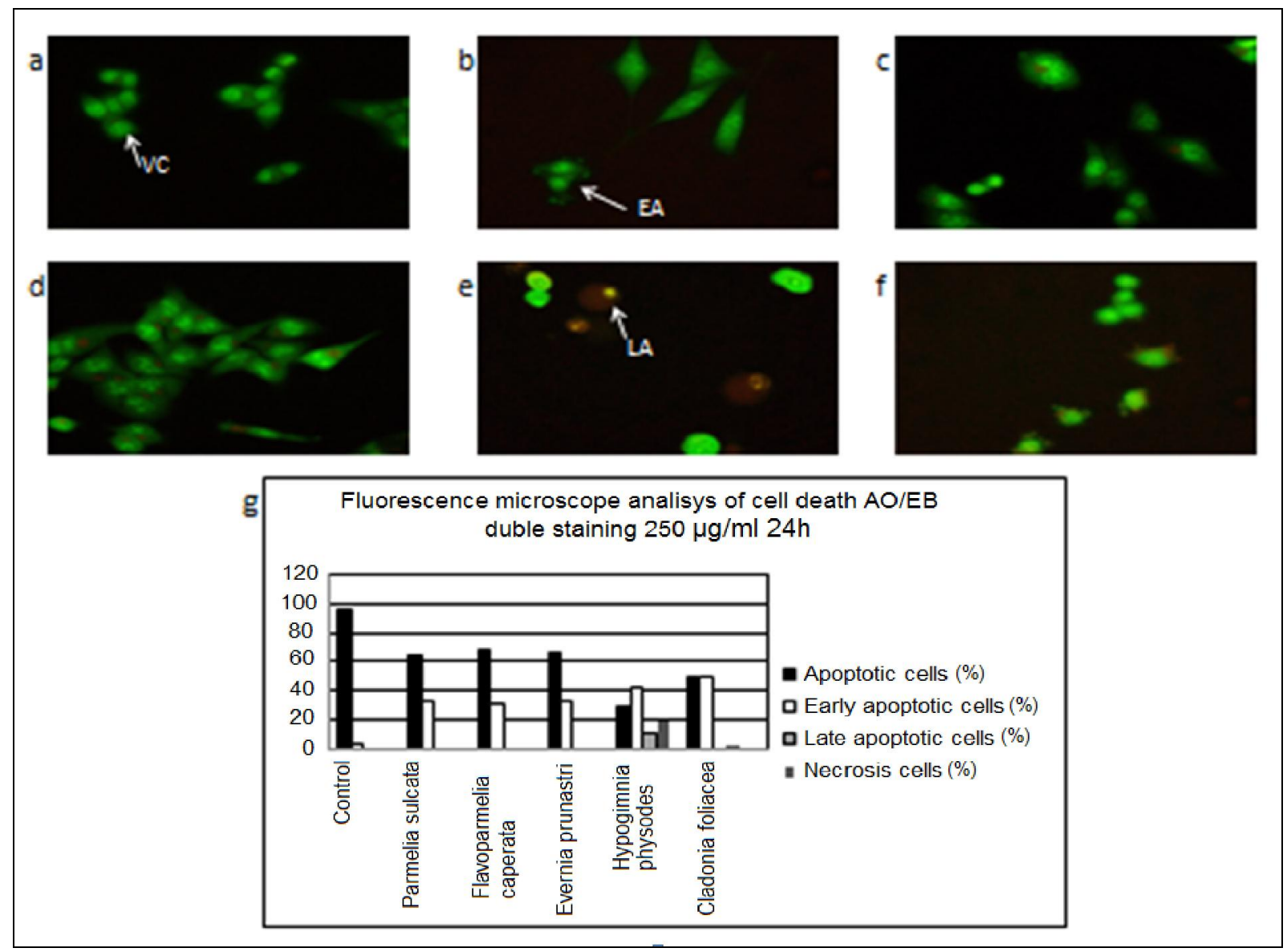

Table 7. Apoptosis of HCT-116 cells induced by $24 \mathrm{~h}$ exposure to the lichen extracts.

\begin{tabular}{|l|c|c|c|c|}
\hline \multicolumn{1}{|c|}{ Lichen extract } & $\begin{array}{c}\text { Viable } \\
\text { cells (\%) }\end{array}$ & $\begin{array}{c}\text { Early apoptotic } \\
\text { cells (\%) }\end{array}$ & $\begin{array}{c}\text { Late apoptotic } \\
\text { cells (\%) }\end{array}$ & $\begin{array}{c}\text { Necrotic cells } \\
\text { (\%) }\end{array}$ \\
\hline None & 96.80 & 3.20 & - & - \\
\hline Parmelia sulcata & 65.36 & 34.02 & 0.41 & 0.20 \\
\hline Flavoparmelia caperata & 68.08 & 31.91 & - & - \\
\hline Evernia prunasti & 66.48 & 33.51 & - & - \\
\hline Hypogymnia physodes & 28.88 & 42.22 & 11.11 & 17.78 \\
\hline Cladonia foliacea & 48.99 & 49.66 & - & 1.34 \\
\hline
\end{tabular}


Figure 3. The effect of the lichen extracts on apoptosis of HCT-116 cells after $72 \mathrm{~h}$ exposure monitored by the acridine orange/ethidium bromide staining: (a) Untreated, control cells; (b) Cells treated with Parmelia sulcata extract; (c) Cells treated with Flavoparmelia caperata extract; (d) Cells treated with Evernia prunastri extract; (e) Cells treated with Hypogymnia physodes extract; (f) Cells treated with Cladonia foliacea extract. Magnification on fluorescent microscope was 400×; (g) Grafic representation of obtained data. VC - viable cell, EA - early apoptotic cell, LA - late apoptotic cell, N - necrotic cell.

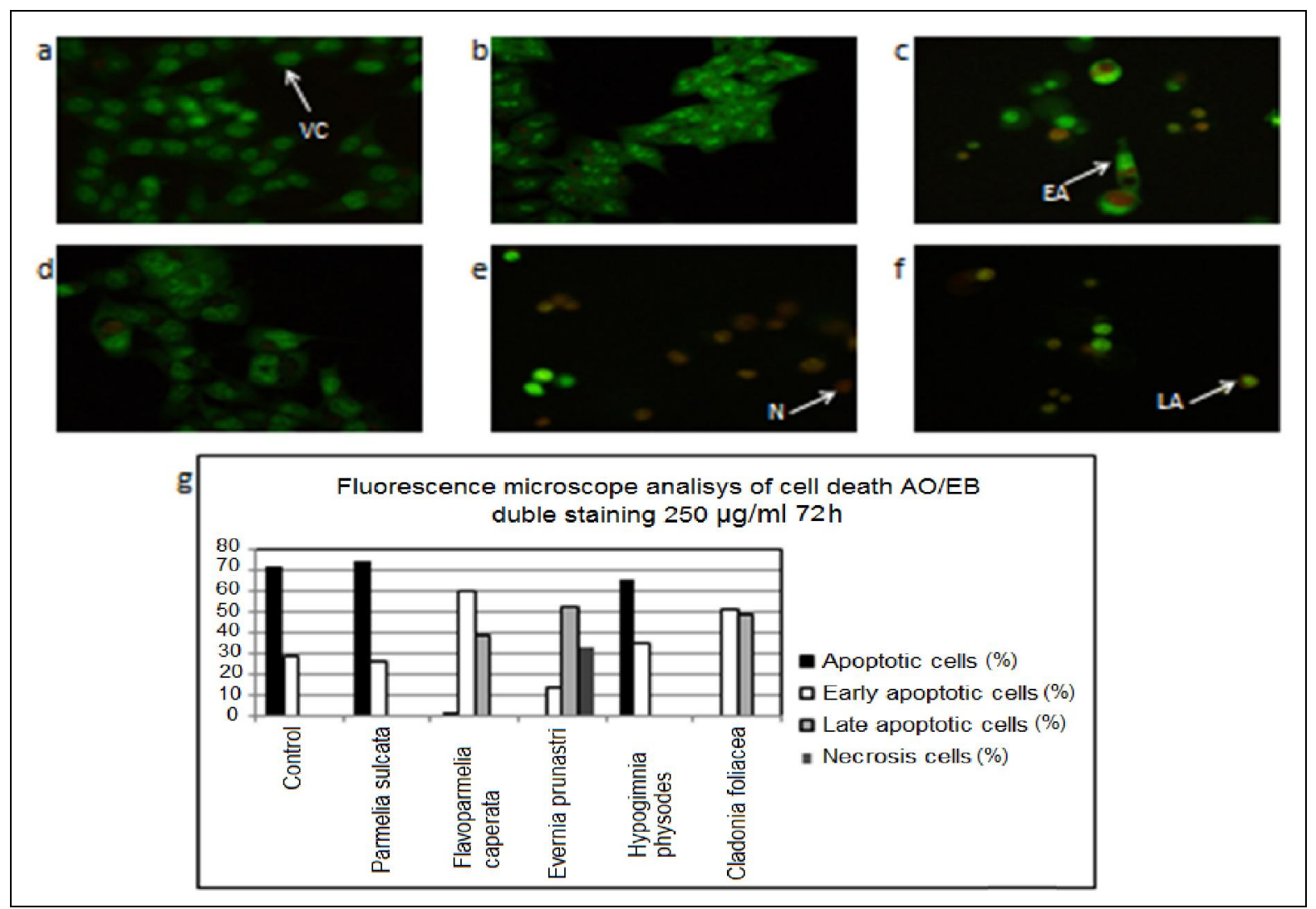

Table 8. Apoptosis of HCT-116 cells induced by $72 \mathrm{~h}$ exposure to the lichen extracts.

\begin{tabular}{|l|c|c|c|c|}
\hline \multicolumn{1}{|c|}{ Lichen extract } & $\begin{array}{c}\text { Viable cells } \\
(\mathbf{\% )}\end{array}$ & $\begin{array}{c}\text { Early apoptotic } \\
\text { cells (\%) }\end{array}$ & $\begin{array}{c}\text { Late apoptotic } \\
\text { cells (\%) }\end{array}$ & $\begin{array}{c}\text { Necrotic } \\
\text { cells (\%) }\end{array}$ \\
\hline None & 71.12 & 28.88 & - & - \\
\hline Parmelia sulcata & 73.66 & 26.20 & 0.20 & - \\
\hline Flavoparmelia caperata & 1.80 & 59.72 & 38.46 & - \\
\hline Hypogimnia physodes & - & 14.21 & 53.15 & 32.62 \\
\hline Evernia prunasti & 65.60 & 34.39 & - & - \\
\hline Cladonia foliacea & - & 51.59 & 48.40 & - \\
\hline
\end{tabular}

A longer exposure (72 h) of HCT-116 cells to the lichen extract enhanced apoptosis (Figure 3 and Table 8). Compared to the spontaneous apoptosis observed in control cells (early apoptotic cells $28.80 \%, 0 \%$ late apoptotic and $0 \%$ necrotic cells), a progress toward late apoptosis and an obvious nuclear condensation were noticed in the treated cells. The extract of Hypogymnia physodes showed the most prominent effect by increasing late apoptosis (53.15\%) and necrosis (32.62\%) 
$\left(\mathrm{IC}_{50}=102.40 \mu \mathrm{g} / \mathrm{mL}\right)$ (Figure 3e). The extract of Cladonia foliacea exerted progression toward late apoptosis $(48.40 \%)$ (Figure $3 \mathrm{f})$.

Our study is the first attempt to evaluate the antiproliferative activity of lichen species on our territory. Bezivin and colleagues investigated cytotoxic activity of eight French lichen species, including Parmelia caperata and Evernia prunastri [23]. They performed extraction with solvents of increasing polarity (n-hexane, diethyl ether and methanol). Although the percentage of apolar, mid-polar and polar compounds was different between species, some similarities inside a genus were observed. The highest quantities of compounds were extracted with methanol regardless of the lichen species. n-hexane fraction of Parmelia caperata was the most active on DU145 (human brain metastasis of prostate carcinoma) cells whereas methanol fraction was selectively cytotoxic on DU145, 3LL (murine Lewis lung carcinoma) and U251 (human glioblastoma) cells. n-hexane extract of Evernia prunastri demonstrated cititoxicity on DU145 cells and its methanol extract on 3LL cells. Bezivin et al. considered the involvement of usnic acid, as a major compound of n-hexane fraction of the mentioned lichen species, in cytotoxic activity on cancer cell lines.

An extract of Hypogymnia physodes and Cladonia foliacea with their prominent apoptotic potential in this study could be useful as a desirable strategy for cancer control, similar to many commercially available chemotherapeutic agents and folk medicinal plants. Having in mind Hypogymnia physodes abundance in phenolic compounds and its antioxidative power, it could be considered as a cotreatment with some stronger cytotoxic agents, chemotherapy agents (for example cisplatin). Previous reports demonstrated that many side effects of the commonly used chemotherapy agents are a consequence of the induction of oxidative stress, which could be palliated by antioxidant food and plants uptake [48]. However, there is a need to fully substantiate the findings through future comprehensive studies of Hypogymnia physodes and Cladonia foliacea extracts. To further determine the activity and mechanism of their action, we should isolate and identify the active principle(s).

\section{Experimental Section}

\subsection{Chemicals}

Acetone, methanol, ethyl acetate and sodium hydrogen carbonate were purchased from "Zorka Pharma" Šabac, Serbia. Gallic acid, rutin hydrate, chlorogenic acid and 2,2-diphenyl-1-picrylhydrazyl were obtained from Sigma Chemicals Co., St Louis, MO, USA. Folin-Ciocalteu phenol reagent and aluminium chloride hexahydrate were purchased from Fluka Chemie AG, Buchs, Switzerland. Nutrient liquid medium for microorganisms, a Mueller-Hinton broth was obtained from Liofilchem, Italy, while a Sabouraud dextrose broth was obtained from Torlak, Belgrade. An antibiotic doxycycline was purchased from Galenika A.D., Belgrade, Serbia and antimycotic fluconazole from Pfizer Inc., USA. Dulbecco's Modified Eagle Medium, fetal bovine serum, penicillin and streptomycin were obtained from Gibco, Invitrogen, New York, USA. 3-[4,5-dimethylthiazol-2-yl]-2,5diphenyltetrazolium bromide and dimethyl sulfoxide were purchased Sigma, St. Louis, USA. All other solvents and chemicals were of analytical grade. 


\subsection{Lichen Material}

Corticolous lichens species: Hypogymnia physodes (L.) Nyl., (syn: Parmelia duplicata var. douglasicola Gyelnik, Parmelia physodes (L.) Ach., Parmelia oregana Gyelnik; common names: Monk's-hood lichen, Hooded tube lichen, Puffed lichen), Evernia prunastri (L.) Ach. (common name: oakmoss), Flavoparmelia caperata (L.) Hale (syn: Parmelia caperata (L.) Ach.; common name: greenshield lichen), Parmelia sulcata Taylor (common name: shield lichen), growing on the Prunus domestica and Salix sp., were collected in the southeast of Serbia in April 2009. The collection site is Bojanine vode near Niš at $860 \mathrm{~m}$. Terricolous lichen species Cladonia foliacea (syn: Cladonia alcicornis (Leightf.) Fr.) was collected at Jelašnička klisura at $330 \mathrm{~m}$. To determinate lichens we used several standard keys [49-51]. Lichen samples were deposited in the lichenological herbarium of the Department of Biology and Ecology, Faculty of Sciences and Mathematics, University of Niš.

\subsection{Preparation of Lichen Extracts}

Air-dried lichen thalli were ground (10 g of material of each species separately). Extractions were performed with $250 \mathrm{~mL}$ of methanol at room temperature for a period of $24 \mathrm{~h}$. The extracts were filtered using Whatman No.1 filter paper and then concentrated in rotary vacuum evaporator at $40{ }^{\circ} \mathrm{C}$.

\subsection{Total Phenolic Content, Toral Flavonoid Content and Antioxidant Activity}

\subsubsection{Determination of Total Phenolic Content}

The total phenolic content of the lichen extracts was determined spectrophotometrically by Folin-Ciocalteu method [33]. Briefly, $0.5 \mathrm{~mL}$ of methanol extract solution $(1 \mathrm{mg} / \mathrm{mL})$ and $2.5 \mathrm{~mL}$ of 1:10 Folin-Ciocalteau reagent (Fluka Chemie AG, Buchs, Switzerland) were mixed and than $2 \mathrm{~mL}$ of sodium carbonate $(75 \mathrm{~g} / \mathrm{L})$ were added. After $15 \mathrm{~min}$ of incubation at $45^{\circ} \mathrm{C}$, the absorbance at $765 \mathrm{~nm}$ was measured (ISKRA, MA9523-SPEKOL 211). The total phenolic concentration was calculated from gallic acid (GA) (Sigma Chemicals Co., St Louis, MO, USA) calibration curve. Data were expressed as gallic acid equivalents (GA)/g of extract averaged from 3 measurements.

\subsubsection{Determination of Total Flavonoid Content}

The total flavonoid content was evaluated using aluminum chloride [34]. The sample for determination was prepared by mixing a $1 \mathrm{~mL}$ of methanol extract solution $(1 \mathrm{mg} / \mathrm{mL})$ and $1 \mathrm{~mL}$ of aluminum chloride $(20 \mathrm{~g} / \mathrm{L})$. After $1 \mathrm{~h}$ of incubation at room temperature, the absorbance at $415 \mathrm{~nm}$ was measured (ISKRA, MA9523-SPEKOL 211). The total flavonoid concentration in lichen extract was calculated from rutin ( $\mathrm{Ru}$ ) (Sigma Chemicals Co., St Louis, MO, USA) calibration curve and expressed as rutin equivalents $(\mathrm{Ru}) / \mathrm{g}$ of dry extract. Measurements were done in triplicates.

\subsubsection{Determination of Free Radical Scavenging Activity}

The antioxidant activity of lichen extract was evaluated according to scavenging activity of stable radical 2,2-diphenyl-1-picrylhydrazyl (DPPH) (Sigma Chemicals Co., MO, St Louis, USA). DPPH assay was performed by a modified method of [35,36]. Serial dilutions of the extract were made from 
$1000 \mu \mathrm{g} / \mathrm{mL}$ to $0.97 \mu \mathrm{g} / \mathrm{mL}$. $1 \mathrm{~mL}$ of each dilution was mixed with $80 \mu \mathrm{g} / \mathrm{mL}$ DPPH. After $30 \mathrm{~min}$ of incubation in darkness at room temperature, the absorbance was measured at $517 \mathrm{~nm}$ (ISKRA, MA9523-SPEKOL 211). The control sample contained all the reagents except the extract. The percentage of inhibition was calculated using the following equation:

$$
\% \text { inhibition }=\left(\frac{A \text { control }-A \text { sample }}{A \text { control }}\right) \times 100
$$

where A control was the absorbance of the control sample and A sample is the absorbance of extract. $\mathrm{IC}_{50}$ values (concentration of the extract in the reaction mixture which decrease the initial DPPH concentration to $50 \%$ ) were estimated from \% inhibition versus the concentration sigmoidal curve using non-linear regression analysis. The data were presented as mean values \pm standard deviation $(\mathrm{n}=3)$.Chlorogenic acid was used as standard $\left(\mathrm{IC}_{50}\right.$ value $\left.11.65 \pm 0.52\right)$.

\subsection{In Vitro Antimicrobial Assays}

\subsubsection{Test Substances}

Lichen extracts were dissolved in DMSO and then diluted into nutrient liquid medium to achieve a concentration of 5\% DMSO. An antibiotic doxycycline (Galenika A.D., Belgrade, Serbia) was dissolved in nutrient liquid medium, a Mueller-Hinton broth (Torlak, Beograde, Serbia), while an antimycotic fluconazole (Pfizer Inc., USA) was dissolved in Sabouraud dextrose broth (Torlak, Belgrade, Serbia).

\subsubsection{Test Microorganisms}

The antimicrobial activity of methanol extracts of five lichens (Parmelia sulcata, Flavoparmelia caperata, Evernia prunastri, Hypogymnia physodes and Cladonia foliacea) was tested against 29 microorganisms including the 15 strains of bacteria (standard strains: Escherichia coli ATCC 25922, Staphylococcus aureus ATCC 25923, Enterococcus faecalis ATCC 29212, Pseudomonas aeruginosa ATCC 27853, Bacillus subtilis ATCC 6633, and clinical strains: Escherichia coli, Staphylococcus aureus, Enterococcus faecalis, Pseudomonas aeruginosa, Proteus mirabilis, Sarcina lutea, Salmonella enterica, Salmonella typhymirium, Bacillus subtilis and Bacillus cereus); 10 species of filamentous fungi: Aspergillus niger ATCC 16404, Aspergillus fumigatus PMFKG-F23, Aspergillus flavus PMFKG-F24, Aspergillus restrictus PMFKG-F25, Aspergillus niger PMFKG-F26, Penicillium italicum PMFKG-F29, Penicillium digitatum PMFKG-F30, Penicillium chrysogenum PMFKG-F31, Trichothecium roseum PMFKG-F32, Botrytis cinerea PMFKG-F33 and 4 yeast species Candida albicans ATCC 10231, Candida albicans (clinical isolate); Rhodotorula sp. PMFKG-F27 and Saccharomyces boulardii PMFKG-P34. All clinical isolates were a generous gift from the Institute of Public Health, Kragujevac. The other microorganisms were provided from the collection of the Laboratory of Microbiology, Faculty of Science, University of Kragujevac. 


\subsubsection{Suspension Preparation}

The bacterial suspensions and the yeast suspension were prepared by the direct colony method [52]. The colonies were taken directly from the plate and were suspended in $5 \mathrm{~mL}$ of sterile $0.85 \%$ saline. The turbidity of the initial suspension was adjusted by comparing with 0.5 McFarland's standard $\left(0.5 \mathrm{~mL} 1.17 \% \mathrm{w} / \mathrm{v} \mathrm{BaCl}_{2} \times 2 \mathrm{H}_{2} \mathrm{O}+99.5 \mathrm{~mL} 1 \% \mathrm{w} / \mathrm{v} \mathrm{H}_{2} \mathrm{SO}_{4}\right)$. When adjusted to the turbidity of the 0.5 McFarland's standard, the bacteria suspension contains about $10^{8}$ colony forming unites $(\mathrm{CFU}) / \mathrm{mL}$ while the suspension of yeast contains $10^{6} \mathrm{CFU} / \mathrm{mL}$. 1:100 dilutions of the initial suspension were additionally prepared into sterile $0.85 \%$ saline. The suspensions of fungal spores were prepared by a gentle stripping of the spore from the slopes with growing aspergilli. The resulting suspensions were $1: 1000$ diluted in sterile $0.85 \%$ saline.

\subsubsection{Microdilution Method}

The antimicrobial activity was tested by determining the minimum inhibitory concentration (MIC) and minimum microbicidal concentration (MMC) using a microdilution method with resazurin [42]. The 96-well plates were prepared by dispensing $100 \mu \mathrm{L}$ of nutrient broth, Mueller-Hinton broth for bacteria and Sabouraud dextrose broth for fungi and yeasts, into each well. A $100 \mu \mathrm{L}$ from the stock solution of the tested compound (concentration of $80 \mathrm{mg} / \mathrm{mL}$ ) was added into the first row of the plate. Then, twofold, serial dilutions were performed by using a multichannel pipette. The obtained concentration range was from 40 to $0.0098 \mathrm{mg} / \mathrm{mL}$. A $10 \mu \mathrm{L}$ of the diluted bacterial, yeast suspension and suspension of spores was added to each well to give a final concentration of $5 \times 10^{5} \mathrm{CFU} / \mathrm{mL}$ for bacteria and $5 \times 10^{3} \mathrm{CFU} / \mathrm{mL}$ for fungi and yeast. Finally, a $10 \mu \mathrm{L}$ resazurin solution was added to each well inoculated with bacteria and yeast. Resazurin is an oxidation-reduction indicator used for the evaluation of microbial growth. It is a blue non-fluorescent dye that becomes pink and fluorescent when reduced to resorufin by oxidoreductases within viable cells. The inoculated plates were incubated at $37{ }^{\circ} \mathrm{C}$ for $24 \mathrm{~h}$ for bacteria, $28{ }^{\circ} \mathrm{C}$ for $48 \mathrm{~h}$ for the yeast and $28{ }^{\circ} \mathrm{C}$ for $72 \mathrm{~h}$ for filamentous fungi. MIC was defined as the lowest concentration of tested substance that prevented resazurin color change from blue to pink. For filamentous fungi, MIC values of the tested substance were determined as the lowest concentration that visibly inhibited mycelia growth.

Doxycycline and fluconazole were used as a positive control. A solvent control test was performed to study an effect of 5\% DMSO on the growth of a microorganism. It was observed that 5\% DMSO did not inhibit the growth of a microorganism. Also, in the experiment, the concentration of DMSO was additionally decreased because of the twofold serial dilution assay (the working concentration was $2.5 \%$ and lower). Each test included growth control and sterility control. All tests were performed in duplicate and MICs were constant.

The minimum bactericidal and fungicidal concentration was determined by plating $10 \mu \mathrm{L}$ of samples from the wells, where no indicator color change was recorded, on the nutrient agar medium. At the end of the incubation period the lowest concentration with no growth (no colony) was defined as minimum microbicidal concentration. 


\subsection{In Vitro Antiproliferative Assays}

\subsubsection{Cell Lines}

The colon cancer adenocarcinoma cell line HCT-116 was obtained from the American Tissue Culture Collection (Manassas, VA, USA). These cells were maintained in Dulbecco's Modified Eagle Medium (DMEM) (Gibco, Invitrogen, New York, USA) containing 10\% fetal bovine serum (FBS), $100 \mathrm{IU} / \mathrm{mL}$ penicillin and $100 \mu \mathrm{g} / \mathrm{mL}$ streptomycin. The cells were grown in $75 \mathrm{~cm}^{2}$ flasks (SARSTEDT AG \& Co., Nümbrecht, Germany) and after a few passages the cells were seeded in 96-well plate. Cells were cultured in a humidified atmosphere of $5 \% \mathrm{CO}_{2}$ at $37{ }^{\circ} \mathrm{C}$. The cell numbers were determined by trypan blue exclusion.

\subsubsection{MTT Assay}

After 24 and $72 \mathrm{~h}$ of treatment, the cell viability was determined by the MTT (3-[4,5dimethylthiazol-2-yl]-2,5-diphenyltetrazolium bromide) reduction assay [45]. MTT assay is a test of cell proliferation based on colored reaction of mitochondrial dehydrogenase from living cells with MTT. HCT-116 cells were seeded in a 96-well plate ( $10^{4}$ cells per well) and cultivated for $24 \mathrm{~h}$. After that the cells were treated with $100 \mu \mathrm{L}$ of diluted lichen extracts (concentration ranged from 50 to $1000 \mu \mathrm{g} / \mathrm{mL}$ ) 24 and $72 \mathrm{~h}$. The untreated cells served as a control. At the end of the treatment period, MTT (final concentration $5 \mathrm{mg} / \mathrm{mL}$ in PBS) (Sigma, St. Louis, USA) was added to each well, which was then incubated at $37{ }^{\circ} \mathrm{C}$ in $5 \% \mathrm{CO}_{2}$ for $2 \mathrm{~h}$. The colored crystals of the produced formazan were dissolved in DMSO (dimethyl sulfoxide) (Sigma, St. Louis, USA). The absorbance was measured at $550 \mathrm{~nm}$ on Microplate Reader. Cell proliferation (\% viability cells) was calculated as a ratio of the absorbance of the treated group divided by the absorbance of the control group, multiplied by 100 to give percentage of the proliferation.

The antiproliferative effect of each extract was expressed by $\mathrm{IC}_{50}$ (inhibitory dose which inhibits $50 \%$ of cell growth) and by the magnitude of the maximal effect in exposed cells. The $\mathrm{IC}_{50}$ values were calculated from calibration curve by a CalcuSyn computer program.

\subsubsection{Fluorescence Microscopic Analysis of Cell Death (AO/EB) Double Staining}

For the analysis of cell death, we used fluorescent assays of the acridine orange/ethidium bromide ( $\mathrm{AO} / \mathrm{EB})$ double staining. Acridine orange is taken up by both viable and nonviable cells which emit green fluorescence if intercalated into double stranded nucleic acid (DNA) or red fluorescence if bound to single stranded nucleic acid (RNA). Ethidium bromide is taken up only by nonviable cells which emit red fluorescence by intercalation into DNA [46].

HCT-116 cells were grown in a 6-well plate $\left(3 \times 10^{4}\right.$ cells per well) for $24 \mathrm{~h}$. After that, $2 \mathrm{~mL}$ $(250 \mu \mathrm{g} / \mathrm{mL})$ of each lichen's methanol extracts were added and the cells were cultivated for 24 and $72 \mathrm{~h}$. The untreated cells served as a control. The incubation was performed at $37{ }^{\circ} \mathrm{C}$ in an atmosphere of $5 \% \mathrm{CO}_{2}$ and $95 \%$ of relative humidity. After 24 and $72 \mathrm{~h}$ of treatment, $200 \mu \mathrm{L}$ of dye mixture (100 $\mu \mathrm{L}$ of $100 \mathrm{mg} / \mathrm{mL} \mathrm{AO}$ and $100 \mu \mathrm{L}$ of $100 \mathrm{mg} / \mathrm{mL}$ EB in distilled water) was added to each well. 
The suspension was immediately (fast uptake) examined by fluorescence microscopy (NICON Eclipse Ti) at $400 \times$ magnification. A minimum of 300 cells was counted in every sample.

\subsubsection{Statistical Analysis}

The data were expressed as the means \pm standard deviation (SD). All statistical analyses were performed using SPSS package (SPSS for Windows, ver. 17, 2008) (Chicago, IL, USA). Mean differences were established by Student's $t$-test. Data were analyzed using one-way analysis of variance (ANOVA). In all cases $p$ values $<0.05$ were considered statistically significant.

\section{Conclusion}

The antioxidant, antimicrobial and antiproliferative activities of the five lichen species from Familia Parmeliacea (Parmelia sulcata, Flavoparmelia caperata, Evernia prunastri, Hypogymnia physodes and Cladonia foliacea) were demonstrated. The best results were obtained from Hypogymnia physodes and Cladonia foliacea. Further work will be done on the isolation and purification of active components in these species.

\section{Acknowledgments}

This research was supported by the Ministry of Science and Education of the Republic Serbia during activities on project III41018 and III41010. The author thanks to colleagues from Department of Chemistry at Faculty of Science and Mathematics, University of Niš, especially Radosav Palić and Gordana Stojanović, for cooperation on the previous scientific projects and extract supply.

\section{References}

1. Taylor, T.N.; Hass, H.; Remy, W.; Kerp, H. The oldest fossil lichen. Nature 1995, 378, 244.

2. Muggia, L.; Schmitt, I.; Grube, M. Lichens as treasure chests of natural products. SIM News 2009, 59, 85-97.

3. Denton, G.H.; Karlen, W. Lichenometry: its application to Holocene moraine studies in Southern Alaska and Swedish Lapland. Arct. Alp. Res. 1973, 5, 347-372.

4. Molnar, K.; Farkas, E. Current results on biological activities of lichen secondary metabolites: A review. Z. Naturforsch. C. 2010, 65, 157-173.

5. Tiwari, A.K. Imbalance in antioxidant defence and human diseases: Multiple approach of natural antioxidants therapy. Curr. Sci. 2001, 81, 1179-1187.

6. Zhang, W.H.; Lin Han, B.L.; Zhang, H.D. Antioxidant activities of extracts from Areca (Areca catectu L.) flower, husk and seed. Electron. J. Environ. Agric. Food Chem. 2009, 8, 740-748.

7. Behera, B.C.; Veram, N.; Sonone, A.; Makhija, U. Evaluation of antioxidant potential of the cultured mycobiont of a lichen Usnea ghattensis. Phytother. Res. 2003, 19, 58-64.

8. Behera, B.C.; Veram, N.; Sonone, A.; Makhija, U. Antioxidant and antibacterial properties of some cultured lichens. Bioresource Technol. 2008, 99, 776-784. 
9. Toledo Marante, F.J.; Garcia Castellano, A.; Estevez Rosas, F.; Quintana Aguiar, J.; Bermejo Barrera, J. Identification and quantification of allelochemicals from the lichen Lethariella canariensis: phytotoxicity and antioxidant activity. J. Chem. Ecol. 2003, 29, 2049-2071.

10. Kinoshita, K.; Togawa, T.; Hiraishi, A.; Nakajima, Y.; Koyama, K.; Narui, T. Antioxidant activity of red pigments from the lichens Lethariella sernanderi, Lethariella cashmeriana and Lethariella sinensis. J. Nat. Med. 2010, 64, 85-88.

11. Ranković, B.; Ranković, D.; Marić, D. Antioxidant and antimicrobial activity of some Lichen species. Microbiology 2010, 79, 809-815.

12. Ranković, B.; Ranković, D.; Kosanić, M.; Marić, D. Antioxidant and antimicrobial properties of the lichens Anaptychya ciliaris, Nephroma parile, Ochrolechia tartarea and Parmelia centrifuga. Cent. Eur. J. Biol. 2010, 5, 649-655.

13. Kosanić, M.; Ranković, B.; Vukojević, J. Antioxidant properties of some lichen species. J. Food Sci. Technol. 2010, 47, 1-7.

14. Kosanić, M.; Ranković, B. Lichen as possible sources of antioxidants. Pak. J. Pharm. Sci. 2011, 24, 165-170.

15. Manojlovic, N.T.; Novakovic, M.; Stevovic, V.; Solujic, S. Antimicrobial metabolites from three Serbian Caloplaca. Pharm. Biol. 2005, 43, 718-722.

16. Manojlovic, N.T.; Novakovic, M.; Stevovic, V.; Solujic, S. Antifungal activity of Rubia tinctorum, Rhamnus frangula and Caloplaca cerina. Fitoterapia 2005, 76, 244-246.

17. Ranković, B.; Misić, M.; Sukdolak, S. Antimicrobial activity of extracts of the lichens Cladonia furcata, Parmelia caperata, Parmelia pertusa, Hypogymnia physodes and Umbilicaria polyphylla. Brit. J. Biomed. Sci. 2007, 64, 143-148.

18. Ranković, B.; Mišić, M.; Sukdolak, S. Evaluation of antimicrobial activity of the lichens Lasallia pustulata, Parmelia sulcata, Umbilicaria crustulosa, and Umbilicaria cylindrica. Microbiology 2007, 70, 723-727.

19. Ranković, B.; Mišić, M.; Sukdolak, S. The antimicrobial activity of substances derived from the lichen Physcia aipolia, Umbilicaria polyphylla, Parmelia caperata and Hypogymnia physodes. World J. Microbiol. Biotechnol. 2008, 24, 1239-1242.

20. Ranković, B.; Mišić, M. The antimicrobial activity of the lichen substances of the lichens Cladonia furcata, Ochrolechia androgyna, Parmelia caperata and Parmelia conspresa. Biotechnol. Biotechnol. Equip. 2008, 22, 1013-1016

21. Ranković, B.; Mišić, M.; Sukdolak, S. Antimicrobial activity of extracts of the lichens Cladonia furcata, Parmelia caperata, Parmelia pertusa, Hypogymnia physodes and Umbilicaria polyphylla. Biologia 2009, 64, 53-58.

22. Perry, N.B.; Benn, M.H.; Brennan, N.J.; Burgess, E.J.; Ellis, G.; Galloway. D.J.; Lorimer, S.D.; Tangney, S. Antimicrobial, antiviral and cytotoxic activity of New Zealand lichens. Lichenologist 1999, 31, 627-636.

23. Bezivin, C.; Tomasi, S.; Lohezic-Le Devehat, F.; Boustie, J. Cytotoxic activity of some lichen extracts on murine and human cancer cell lines. Phytomedicine 2003, 10, 499-503.

24. Ingolfsdottir, K. Usnic acid. Phytochemistry 2002, 61, 729-736. 
25. Ogmundsdottir, H.M.; Zoega, G.M.; Gissurarson, S.R.; Ingolfsdottir, K. Anti-proliferative effects of lichen-derived inhibitors of 5-lypoxygenase on malignant cell-lines and mitogen stimulated lymphocytes. J. Pharm. Pharmacol. 1998, 50, 107-115.

26. Bucar, F.; Schneider, I.; Ogmundsdottir, H.; Ingolfsdottir, K. Anti-proliferative lichen compounds with inhibitory activity on 12(S)-HETE production in human platelets. Phytomedicine 2004, 11, 602-606.

27. Culberson, C.F. Chemical and Botanical Guide To Lichen Products; University of North Carolina Press: Chapell Hill, NC, USA, 1969; p. 628.

28. Stojanović, I.; Radulović, N.; Mitrović, T.; Stamenković, S.; Stojanović, G. Volatile constituents of selected Parmeliaceae lichens. J. Serb. Chem. Soc. 2011, 76, 987-994.

29. Stojanović, Gordana. University of Niš, Niš, Serbia. Unpublished work, 2010.

30. Arup, U.; Ekman, S.; Lindblom, L.; Mattsson, J. High performance thin layer chromatography (HPTLC), an improved technique for screening lichen substances. Lichenologist 1993, 25, 61-71.

31. Hauck, M.; Huneck, S. Lichen substances affect metal adsorption in Hypogymnia physodes. $J$. Chem. Ecol. 2007, 33, 219-223.

32. Yılmaz, M.; Türk, A.Ö.; Tay, T.; Merih, K. The antimicrobial activity of extracts of the lichen Cladonia foliacea and its (+)-usnic acid, atranorin, and fumarprotocetraric acid constituents. $Z$. Naturforsch. 2004, 59, 249-254.

33. Singleton, V.L.; Orthofer, R.; Lamuela, R.R.M. Analysis of total phenols and other oxidation substrates and antioxidants by means of Folin-Ciocalteu reagent. Meth. Enzymology 1999, 299, $152-178$.

34. Quettier, D.C.; Gressier, B.; Vasseur, J., Dine, T.; Brunet, C.; Luyckx, M.C.; Cayin, J.C.; Bailleul, F.; Trotin, F. Phenolic compounds and antioxidant activities of buckwheat (F. esculentum Moench) hulls and flour. J. Ethnopharmacol. 2000, 72, 35-42.

35. Tekao, T.; Watanabe, N.; Yagi, I.; Sakata, K. A simple screening method for antioxidant and isolation of several antioxidants produced by marine bacteria from fish and shellfish. Biosci. Biotechnol. Biochem. 1994, 58, 1780-1783.

36. Kumarasamy, Y.; Byres, M.; Cox, P.J.; Jasapars, M.; Nahar, L.; Sarker, S.D. Screening seeds of some Scottish plants for free-radical scavenging activity. Phytother. Res. 2007, 21, 615-621.

37. Odabasoglu, F.; Aslan, A.; Cakir, A.; Suleyman, H.; Karagoz, Y.; Halici, M.; Yasin B. Comparasion of antioxidant activity and phenolic content of three lichen species. Phytother. Res. 2004, 18, 938-941.

38. Muller, K. Pharmaceutically relevant metabolites from lichens. Appl. Microbiol. Biotechnol. 2001, 56, 9-16.

39. Bartak, M.; Hajek, J.; Vrablikova, H.; Dubova, J.. High-light stress and photoprotection in Umbilicaria antartica monitored by chlorophyl fluorescence imaging and changes in yeaxanthin and glutathione. Plant Biol. 2004, 3, 331-341.

40. Weissman, L.; Garty, J.; Hochman, A. Characterization of enzymatic antioxidants in the lichen Ramalina lacera and their response to rehydration. Appl. Environ. Microbiol. 2005, 71, 6508-6514. 
41. Weissman, L.; Fraiberg, M.;Shine, L.; Garty, J.; Hochman, A. Responses of antioxidant in the lichen Ramalina lacera may serve as early-warning bioindicator system for detection of air pollution stress. FEMS Microbiol. Ecol. 2006, 58, 41-53.

42. Sarker, S.D.; Nahar, L.; Kumarasamy, Y. Microtitre plate-based antibacterial assay incorporating resazurin as an indicator of cell growth, and its application in the in vitro antibacterial screening of phytochemicals. Methods 2007, 42, 321-324.

43. Cansaran-Duman, D.; Cetin, D.; Simsek, H.; Coplu, N. Antimicrobial activities of the lichens Hypogymnia vittata, Hypogymnia physodes and Hypogymnia tubulosa and HPLC analysis of their usnic acid content. Asian J. Chem. 2010, 22, 6125-6132.

44. Candan, M.; Yilmaz, M.; Tay, T.; Erdem, M.; Turk, A.O. Antimicrobial activity of extracts of the lichen Parmelia sulcata and its salazinic acid constituent. Z. Naturforsch. C 2007, 62, 619-621.

45. Mosmann, T. Rapid colorimetric assay for cellular growth and survival: application to proliferation and cytotoxicity assays. J. Immunol. Meth. 1983, 65, 55-63.

46. Baskić, D.; Popović, S.; Ristić, P.; Arsenijević, N.N. Analysis of cycloheximide-induced apoptosis in human leukocytes: Fluorescence microscopy using annexin V/propidium iodide versus acridin orange/ethidium bromide. Cell Biol. Int. 2006, 30, 924-932.

47. Itharat, A.; Houghton, P.J.; Eno-Amooquaye, E.; Burke, P.J.; Sampson, J.H.; Raman, A. In vitro cytotoxic activity of Thai medicinal plants used traditionally to treat cancer. J. Ethnopharmacol. 2004, 90, 33-38.

48. Cetin, R.; Devrim, E.; Kilicoglu, B.; Avci, A.; Candir, O.; Durak, I. Cisplatin impairs antioxidant system and causes oxidation in rat kidney tissues: Possible protective roles of natural antioxidant foods. J. Appl. Toxicol. 2006, 1, 42-46.

49. Wirth, V. Die Flechten Baden-Würtembergs, Verbreitungsatlas, 1\&2; Eugen Ulmer GmbH\&Co: Stuttgart, Germany, 1995.

50. Boqueras, M. Líquens epífits i fongs liquenícoles del sud de Catalunya: flora i comunitats; Institut d'Estudis Catalans: Barcelona, Spain, 2000.

51. Dobson, F.S. Lichens; The Richmond Publishing Co. Ltd.: Richmond, UK, 2005.

52. Andrews J.M.; BSAC Working Party on Susceptibility Testing. BSAC standardized disc susceptibility testing method. J. Antimicrob. Chemother. 2005, 56, 60-76.

(C) 2011 by the authors; licensee MDPI, Basel, Switzerland. This article is an open access article distributed under the terms and conditions of the Creative Commons Attribution license (http://creativecommons.org/licenses/by/3.0/). 